\title{
In quest of cyrtocrinid origins: Evidence from Late Triassic ossicles from the Tatra Mountains
}

Mariusz A. Salamon, Przemysław Gorzelak, and Michał Zatoń

Acta Palaeontologica Polonica 54 (1), 2009: 171-174 doi:http://dx.doi.org/10.4202/app.2009.0119

We report cyrtocrinid (Crinoidea) ossicles from the Rhaetian (Late Triassic) of the TatraMountains (southern Poland). The columnals are high, the facets are covered with thick crenulae and the latera are concave. Such features of symplectial articulation and latera distinguish them from the columnals of other Triassic crinoids (i.e., millericrinids and encrinids) and therefore we consider they belong to Cyrtocrinida. The oldest representatives of cyrtocrinids were known from the Early Jurassic, therefore the presented material constitutes the oldest world record of these crinoids to date. We speculate that perturbations related to the global mid-Carnian extinction combined with predation intensity observed in the Middle-Late Triassic have been involved in early origin of Cyrtocrinida.

Mariusz A. Salamon [paleo.crinoids@poczta.fm] and Michał Zatoń [mzaton@wnoz.us.edu.pl ], Wydział Nauk o Ziemi, Uniwersytet Śląski, ul. Będzińska 60, PL-41-200

Sosnowiec, Poland; Przemysław Gorzelak [pgorzelak@twarda.pan.pl], Instytut Paleobiologii PAN, ul. Twarda 51/55, PL-00-818 Warszawa, Poland.

This is an open-access article distributed under the terms of the Creative Commons Attribution License (for details please see creativecommons.org), which permits unrestricted use, distribution, and reproduction in any medium, provided the original author and source are credited. 